\title{
Quality and Energy Evaluation in Meat Cooking
}

\author{
Pankaj B. Pathare ${ }^{1}$ Anthony Paul Roskilly ${ }^{1}$
}

Received: 27 November 2015/ Accepted: 28 March 2016/Published online: 5 April 2016

(C) The Author(s) 2016. This article is published with open access at Springerlink.com

\begin{abstract}
Consumer acceptance of meat is strongly influenced by the eating quality. Cooking method has great impact on eating quality of meat, and energy consumption is important parameter to consider while selecting the cooking method. Energy requirement for well-cooked meats varies with cooking method, appliances and consumer behaviour. Energy consumption reduction during meat cooking may have the influence on global energy requirement. This article critically reviewed the effects on quality characteristics of meat and meat products by different cooking methods. The different cooking methods including oven, frying, sous vide and ohmic cooking are discussed in detail, and their effects on meat quality parameters such as colour, tenderness, cooking loss, shrinkage and juiciness are also presented. Highlighting on the role of cooking process on meat quality, energy requirement for cooking were identified.
\end{abstract}

Keywords Meat cooking - Tenderness - Cooking loss · Thermal diffusivity $\cdot$ Cooking energy

\section{Introduction}

Meat is a basic portion of sound and all-round balanced diet due to its nutritional richness. Meat is a valuable wellspring of high natural quality protein and also other B complex vitamins, zinc, selenium, iron, vitamin B12 and phosphorus [92]. Offal meats like liver are also vital

Pankaj B. Pathare

pankaj.pathare@ncl.ac.uk; pbpathare@yahoo.co.in

1 Sir Joseph Swan Centre for Energy Research, Newcastle University, Newcastle upon Tyne NE1 7RU, UK sources of vitamin A and folic acid [9]. Meat is a complex food with a structured nutritional composition [8].

Meat and meat-based products are cooked before being eaten. Cooking step is critical for destroying foodborne pathogens, assuring microbial safety and achieving meat quality. Cooking also has an important effect on the nutritional properties and same time on its possible toxicity [62]. With cooking meat becomes edible and more digestible [8]. Generally, consumer chooses a cooking method that produces a high-quality meat products having favourable texture and taste [61]. The United States Department of Agriculture (USDA) recommended the internal temperature for different meat such as $62.8^{\circ} \mathrm{C}$ for steaks, roasts and fish, $71.1{ }^{\circ} \mathrm{C}$ for pork and ground beef, $76.7{ }^{\circ} \mathrm{C}$ for chicken breasts and $82{ }^{\circ} \mathrm{C}$ for whole chicken [61]. Physical properties and eating quality of meat are affected by cooking temperature and time. During cooking, the distinctive meat proteins are denatured and this reasons structural changes in the meat textural profile. These resulted in destruction of cell membranes, shrinkage of meat fibres, the aggregation and gel formation of myofibrillar and sarcoplasmic proteins, and shrinkage and solubilization of the connective tissue [119]. Heat treatment can result to undesirable meat quality changes, such as nutritive value loss because of lipid oxidation and changes in a few segments of the protein fraction. [101].

Cooking consumes large amount of energy and releases lots of greenhouse gas (GHG) emissions [131]. Selection of cooking method, fuel and cookware are beneficial for reducing the carbon footprint of the cooking unit. Furthermore, the correct use and improved performance of cookware could decrease emissions of all the pollutants per unit of useful heat. The meat structure, size and state of the cookware had impact on energy utilization. Consumer's behaviours also have big influence on energy demand 
during cooking. Cooking energy demand increases up to two times if consumers are not aware of energy-saving techniques during cooking [43].

The purpose of this review is to provide an overview of different cooking methods on meat quality parameters and the impact on energy requirement. The effects of meat cooking on thermal properties and quality characteristics, such as tenderness, juiciness and shrinkage are discussed. In addition, it is important to inform the consumers how to properly handle and cook energy-efficient meat products.

\section{Meat Cooking: An Overview}

Eating quality of meat is mainly affected by applied cooking method. The quality characteristics of meat products change considerably depending on the type and intensity of the heat treatment applied. [6]. Distinctive heat transfer media has been utilized for meat cooking which incorporates dry heat methods, moist heat methods or microwave cooking. The choice of appropriate cooking techniques relies on the type of meat, the amount of connective tissue, size and shape of the meat. The different cooking methods commonly used for meat preparation are discussed below.

\section{Oven Cooking}

Oven cooking is broadly utilized in commercial processing and foodservice operations [76]. Quality attributes and microbial safety of products have been affected by oven cooking or roasting [42]. An oven empowers heating of meat at raised temperatures normally up to $250{ }^{\circ} \mathrm{C}$. Rapid rate of heating due to high cooking temperature reduces the total cooking loss of meat. [87]. The reduction in total cooking loss is important as meat promotes higher solubilization of intramuscular collagen-based connective tissue leading towards tenderization due to high waterholding capacity. During roasting, the first period of toughening happens because of the denaturation of myofibrillar proteins. Subsequently, toughening is further escalated from the shrinkage of intramuscular collagen, followed by a final increment in toughness when the shrinkage and dehydration of the myofibrillar proteins take place [4].

In oven cooking, surface dehydration prevention and cooking time reduction have been done by coupling the forced air convection method with steam injection in the oven chamber [78]. Application of air/steam treatments accomplished the exact heat control of a convection oven and the efficiency of steam cooking with the ensuing reduction lessening in cooking time [20]. Steam induction into the oven chamber during cooking makes heat and mass transfer more complex as it increases the heat transfer and the surface water evaporation process is modified. Generally, the oven temperatures higher than $150{ }^{\circ} \mathrm{C}$ have been used for meat roasting; however, lower cooking temperature could reduce energy with beneficial effect for domestic and commercial catering operations. And the induction of steam accelerated the cooking process, increases the overall heat transfer coefficient and reduces the cooking time [124]. Murphy et al. [78] reported that the heat flux is firmly related with the relative humidity of the oven air and results in diverse meat heating profiles.

High cooking temperatures enhance colour and flavour and lessens the cooking times however diminish meat tenderness and juiciness. On the other hand, high relative humidity builds the heat transfer and meat juiciness yet lessening flavour and colour development [100].

Mora et al. [76] compared forced convection (dry air, $\mathrm{RH}=8 \%)$, low steam $(\mathrm{RH}=35 \%)$ and high steam $(\mathrm{RH}=88 \%)$ oven cooking at $100{ }^{\circ} \mathrm{C}$ for turkey meat cooking. Low steam cooking enhanced quality of turkey meat and lessened water utilization, and it should be consider as an alternative to steam saturation cooking.

\section{Frying}

Frying is a cooking technique where fat or oil is utilized as the heat transfer medium, in direct contact with the food [122]. Heat is transmitted by contact between the pan and the meat. Frying is complex process due to coupled heat and mass transfer between meat and frying medium. Simultaneous heat and mass transfer of oil and air promote a number of chemical changes, such as moisture loss, oil uptake, crust formation, gelatinization of starch, aromatization, protein denaturation and colour change via maillard reactions, hydrolysis or oxidation, and oil polymerization [74].

Immersing frying can be characterized by four stages [38]. During the first stage, heat transfer is by convection and food surface heats up to the boiling point of water. Surface water starts to boil and evaporate in the second stage. Therefore, heat transfer between the oil and the food changes from natural convection to forced convection because of turbulence in the oil. This enhances the heat transfer coefficient. Dehydration of surface and high temperature reason crust layer formation in this stage. In the third stage, temperature in the inward area of the food builds gradually to boiling point of water. Physicochemical changes like starch gelatinization and protein denaturation happen in this stage. Also, crust layer thickness expands and water vapour transfer at the surface lessens. At the last stage, surface evaporation stops and no air pockets are seen on the surface of the food [2]. 
Frying temperature is a crucial component to the extent meat flavour, cooking time and weight loss of products. The cooking time is generally short due to the high frying temperature, and the meat surface gets to be brown due to maillard reaction.

\section{Sous Vide Cooking}

Sous vide is defined as the method of heating raw meat packed inside a vacuum pouch in a water bath at a specified temperature [123]. The technique is also known as the "cook-in-bag" system. In sous vide cooking, typical temperatures around $50-85{ }^{\circ} \mathrm{C}$ are used, thus it requires longer heating times compared to conventional cooking methods.

Sous vide cooking maintained the lower temperature, which minimizes the temperature gradient and reduces the damage to heat sensitive proteins and supplements. It also reduces cooking loss and preserves the juiciness [31, 123]. Low temperature in sous vide method has a positive effect on meat tenderness. And the extended cooking time builds collagen solubility [6]. In sous vide cooking, the tenderization of the connective tissue takes place through the solubilization of the intramuscular collagen inside the moist in-pack environment [40, 47]. Sous vide cooking is promoted for its ability to retain nutrients, enhance flavour and texture in a manner that conventional roasting can not deliver [77].

Vaudagna et al. [123] used sous vide method for beef muscles cooking by applying different low temperature with long time treatments. Higher cooking loss and lower shear force values have been found when the temperature increased from 50 to $65{ }^{\circ} \mathrm{C}$. There were no significant effect of the processing times (90-360 min) on cooking loss and shear force. The colour parameter $a^{*}$ value decreased as processing temperature increased. GarcíaSegovia et al. [40] also reported the similar observation.

\section{High-Pressure Processing}

High-pressure processing (HPP), also known as high hydrostatic pressure (HHP) treatment, is used by the food industry for microbial inactivation coupled with preservation of food quality [27, 50, 60]. High-pressure processing induces meat protein modifications differently than heatinduced changes [111].

HPP treatment has created diverse textures on food with minimal effects on flavour, colour and nutrient stability [116, 121]. HPP increases the solubility of myofibrillar proteins as a consequence of depolymerization of protein molecules, which improves gelation and meat tenderness $[18,116]$. Pressure is highly effective in accomplishing desirable tenderization of myofibrillar proteins, and it has little impact on the intramuscular collagen in the connective tissue that are settled by hydrogen bonds [116]. Mor-Mur and Yuste [75] reported that the high-pressure treatment $\left(500 \mathrm{MPa}\right.$ and $65^{\circ} \mathrm{C}$ ) of cooked sausages produces less firm, more cohesive products with less weight loss compared to heat-pasteurized sausages cooked at $80-85{ }^{\circ} \mathrm{C}$ for $40 \mathrm{~min}$.

\section{Ohmic Heating}

Ohmic heating is an electro-heating technique. It involves the utilization of the electricity to a food material, bringing about volumetric heat generation [115]. The system depends on the entry of electrical current through a food item that has electrical resistance [51]. Electrical energy is converted into the heat, and the heat generation relies on the voltage gradient and electrical conductivity [103]. And it resulted in efficient rising in internal temperature of food [125].

Ohmic cooking in meat products resulted in faster cooking, less power consumption and safer product [86]. Ohmically cooking produces a firmer sample than conventional cooking [14]. Ohmic heating resulted in cooking loss reduction and improved juiciness [135]. Many researchers showed that ohmic heating could be used as a cooking process for producing safer meat products either alone or in combination with conventional cooking methods [13, 14, 52, 86, 108, 135]. However, ohmic cooking is an inefficient cooking method for desirable changes in surface colour and texture in meat products [13, 14, 134]. Heterogeneous structure of meat samples affects the uniform heat distribution such as fat in meat product do not generate the heat at same rate as muscle [109]. Such difficulties are encountered in applying ohmic treatment to meat and meat products.

Zell et al. [135] used ohmic heating and steam cooking for whole beef muscle. Ohmically cooked meat had a significantly uniform lighter and less red colour, and less cooking loss but tougher texture compared to steamcooked meat.

\section{Effect on Different Quality Parameter}

Cooking of meat plays a vital role to achieve a palatable and safe product [119]. Also, it may influence essential qualities identified with consumer's inclinations, as flavour and tenderness [93]. Cooking methods affect the nutritive values of meat. Generally, heat is applied to meat in different approaches to enhance its hygienic quality by inactivation of pathogenic microorganisms and to enhance its flavour and taste, and increase shelf life [11, 94]. Meat nutritional values could be modified due to physicochemical reactions during cooking. Cooking instigates water loss 
in the food, expanding its lipid content, while some fat is lost [39]. Cooking reasons structural changes, which diminish the water-holding capacity of the meat. Shrinkage on cooking causes the most noteworthy water loss at $60-70{ }^{\circ} \mathrm{C}$, and it is assumed that water is removed by the pressure applied by the shrinking connective tissue on the aqueous solution in the extracellular void [119].

Water debinding and migration in meat amid cooking are identified with the denaturation and contraction of protein structures created by expanding temperature [65, $87,119]$. There is up to $80 \%$ water loss from beef burger during pan frying [84]. The effect of different cooking methods on meat quality parameter is discussed below.

\section{Effect on Cooking Loss}

Cooking loss is a combination of liquid and soluble matters lost from the meat during cooking [1, 114]. Cooking loss is a critical factor in meat industry as it determines the technological yield of the cooking process [63]. From a nutritional perspective, cooking loss brought about loss of soluble proteins, vitamins and different supplements [133]. Cooking loss was calculated as the per cent weight difference between fresh and cooked samples with respect to the weight of fresh meat samples [20].

The cooking loss begins to develop around $40{ }^{\circ} \mathrm{C}$. In meat with low $\mathrm{pH}$ (below 5.4 for pork), cooking loss begins as low as around $30{ }^{\circ} \mathrm{C}$. The rate of cooking loss development is greatest between 50 and $70{ }^{\circ} \mathrm{C}$ and after which it falls [6].

Total cooking losses rely on the temperature and rate of heating $[45,87]$. Table 1 presented the effect of different cooking methods on meat cooking loss.

Physical properties of meat and eating quality have been largely affected by cooking temperature and time [22]. With increasing internal meat duck breast muscle temperature, cooking loss gradually increased [67].

Domínguez et al. [34] studied the effect of four different cooking methods (roasting, grilling, microwaving and frying) on cooking loss of foal meat. Microwave cooking resulted in the highest cooking loss, which were in agreement with other researchers [37, 55, 80, 133]. High electromagnetic field, high power and brief time related in microwaving came about protein denaturation, breaking down of the texture matrix, quick protein destruction brought on by heat shock to the proteins and, at long last, liberalization of a lot of water and fat [132].

\section{Effect on Meat Textural Properties}

Tenderness is a textural property which is considered to be the most critical attribute in meat consumption [30, 126]. Consumer satisfaction has been influenced by meat tenderness [110], and it is important to meet the meat tenderness that consumers demand.

Most meat is eaten cooked, and the cooking process is one of the main determinants of tenderness [29, 57]. Cooking has a major influence on the meat tenderness as the water- and fat-binding characteristics, and the texture are closely related to the heating conditions applied [93]. Thermal changes that happen in muscle proteins amid heating and the development of another protein network directly affect product yield, texture, moistness, and general quality [104]. Thermal tenderness of meat after cooking specifically takes up with the net impact of this tenderization and toughening, which relies on upon the cooking conditions [67].

Changes in texture of meat amid cooking are because of the heat-induced structural changes joined with enzymatic breakdown of the proteins. The impact of the time/temperature element and the core temperature relies on the piece of the meat. Tenderness is thought to be the characteristic of eating quality which most impacts consumer acceptability [12, 28, 49]. Heat solubilizes collagen that result in tenderization, though warmth denatures myofibrillar proteins that result in toughening. These heat-induced changes are time and temperature dependent, and the net effect of this toughening or tenderization relies on upon cooking conditions $[67,81]$.

Trained panel or physical methods used for meat tenderness determination. Warner-Bratzler shear force (WBSF) test has been widely used to estimate tenderness of raw and cooked meat as a standard mechanical measurement [23, 41, 70]. The profile indicates either force applied over time or force applied versus the distance that the blade has travelled [41]. Usually, the most considered parameter of the curve is the maximum shear force. Destefanis et al. [30] classified meat into five groups according to their tenderness, namely very tender $(\mathrm{WBSF}<32.96 \mathrm{~N})$, tender $(32.96 \mathrm{~N}<$ WBSF $<42.77 \mathrm{~N}), \quad$ acceptably tender $\quad(42.87 \mathrm{~N}<$ WBSF $<52.68 \mathrm{~N})$, hard $(52.78 \mathrm{~N}<\mathrm{WBSF}<62.59 \mathrm{~N})$ and very hard $(\mathrm{WBSF}>62.59 \mathrm{~N})$. However, there is a general lack of consistency or standards to choose and report a set of tenderness values even among researchers on the same type of meat.

Shear force was taken as an hardness indicator and reported to give more data on the degree of denaturation of the myofibrillar proteins (primarily actomyosin complex) that brought about shrinkage of the muscle fibres, in comparison with alterations of connective tissue component (i.e. collagen shrinkage and gelatinization) after cooking of meat $[44,45]$. Cooking of pork brought on an increment in the force expected to cut the meat demonstrating an increase in hardness (i.e. reduction in tenderness) [20].

James and Yang [54] compared three cooking methods (conventional oven roasting, sous vide and high-pressure 
Table 1 Selected publications on cooking loss during meat cooking

\begin{tabular}{|c|c|c|c|c|}
\hline Produce & Cooking method & Cooking conditions & Cooking loss & References \\
\hline \multirow[t]{3}{*}{ Turkey meat } & Forced convection (dry air, RH-8 \%) & Oven cooking at $100{ }^{\circ} \mathrm{C}$ & $32.2 \%$ & {$[76]$} \\
\hline & Low steam (RH-35 \%) & & $15.9 \%$ & \\
\hline & High steam (RH-88 \%) & & $22.8 \%$ & \\
\hline \multirow[t]{5}{*}{ Goat meat } & \multirow{5}{*}{$\begin{array}{l}\text { Vacuum-packed plastic bags and retorted to the } \\
\text { following internal temperatures }\end{array}$} & $50{ }^{\circ} \mathrm{C}$ & $5.91 \pm 2.54$ & {$[68]$} \\
\hline & & $60{ }^{\circ} \mathrm{C}$ & $8.71 \pm 2.95$ & \\
\hline & & $70{ }^{\circ} \mathrm{C}$ & $15.38 \pm 4.39$ & \\
\hline & & $80{ }^{\circ} \mathrm{C}$ & $33.08 \pm 4.86$ & \\
\hline & & $90{ }^{\circ} \mathrm{C}$ & $41.25 \pm 1.73$ & \\
\hline \multirow{4}{*}{$\begin{array}{l}\text { Foal meat (internal } \\
\text { temperature of } 70^{\circ} \mathrm{C} \text { ) }\end{array}$} & Roasting & $200{ }^{\circ} \mathrm{C} / 12 \mathrm{~min}$ & $26.71 \pm 3.51$ & [34] \\
\hline & Grilling & $130-150{ }^{\circ} \mathrm{C} / 5 \mathrm{~min}$ & $22.45 \pm 5.51$ & \\
\hline & Microwaving & $\begin{array}{l}1000 \mathrm{~W} / 1.5 \mathrm{~min} \text { on } \\
\text { each surface }\end{array}$ & $32.49 \pm 6.41$ & \\
\hline & Frying & $\begin{array}{l}170-180{ }^{\circ} \mathrm{C} / 4 \mathrm{~min} \text { on } \\
\text { each surface }\end{array}$ & $23.73 \pm 2.87$ & \\
\hline \multirow[t]{3}{*}{ Beef } & Oven cooking & $200{ }^{\circ} \mathrm{C} / 15 \mathrm{~min}$ & $31 \%$ & {$[54]$} \\
\hline & Sous vide & $60^{\circ} \mathrm{C} / 60 \mathrm{~min}$ & $19 \%$ & \\
\hline & HPP & $60{ }^{\circ} \mathrm{C} / 30 \mathrm{~min} / 150 \mathrm{MPa}$ & $17 \%$ & \\
\hline \multirow[t]{3}{*}{ Beef } & Sous vide & $50^{\circ} \mathrm{C} / 90 \mathrm{~min}$ & $8.33 \pm 1.71$ & [123] \\
\hline & & $50{ }^{\circ} \mathrm{C} / 390 \mathrm{~min}$ & $10.82 \pm 1.62$ & \\
\hline & & $65^{\circ} \mathrm{C} / 90 \mathrm{~min}$ & $19.41 \pm 1.91$ & \\
\hline \multirow[t]{2}{*}{ Pork lion chop } & Pan frying & $175^{\circ} \mathrm{C} / 75 \mathrm{~s}$ & $11.26 \pm 2.19$ & {$[66]$} \\
\hline & & $175^{\circ} \mathrm{C} / 150 \mathrm{~s}$ & $24.75 \pm 3.00$ & \\
\hline \multirow[t]{4}{*}{ Muscovy drake meat } & Pan frying & $180^{\circ} \mathrm{C} / 5$ min per side & 43.36 & [83] \\
\hline & Deep frying & $180{ }^{\circ} \mathrm{C} / 10 \mathrm{~min}$ & 52.37 & \\
\hline & Gas grilling & $200{ }^{\circ} \mathrm{C} / 10$ min per side & 44.40 & \\
\hline & Roasting & $200{ }^{\circ} \mathrm{C} / 20 \mathrm{~min}$ & 43.02 & \\
\hline \multirow[t]{4}{*}{ Mutton chops } & Grilling (internal temperature) & $51^{\circ} \mathrm{C}$ & 5.5 & [105] \\
\hline & & $65^{\circ} \mathrm{C}$ & 12 & \\
\hline & & $71{ }^{\circ} \mathrm{C}$ & 16.5 & \\
\hline & & $79^{\circ} \mathrm{C}$ & 31.4 & \\
\hline \multirow[t]{2}{*}{ Pork } & Ohmic heating & EPTs $\left(60-100^{\circ} \mathrm{C}\right)$ & $9.71-30.22$ & [24] \\
\hline & Water bath & & $22.53-38.51$ & \\
\hline \multirow[t]{3}{*}{ Whole turkey meat } & Ohmic treatment & LTLT $\left(72{ }^{\circ} \mathrm{C} / 15 \mathrm{~min}\right)$ & 25.2 & [136] \\
\hline & Ohmic treatment & $\mathrm{HTST}\left(95^{\circ} \mathrm{C} / 8 \mathrm{~min}\right)$ & 31.3 & \\
\hline & Conventional treatment & $\begin{array}{l}\left(72{ }^{\circ} \mathrm{C} \text { end point }\right. \\
\text { temperature) }\end{array}$ & 27.0 & \\
\hline Meatball & Ohmically cooked (centre temperature) & $75{ }^{\circ} \mathrm{C}$ & $15.57 \pm 1.61$ & [106] \\
\hline \multirow[t]{3}{*}{ Pork ham } & Dry air cooking & $120^{\circ} \mathrm{C}$ & 22.25 & [19] \\
\hline & Wet air cooking & $82^{\circ} \mathrm{C}$ & 12.74 & \\
\hline & Water cooking & $82{ }^{\circ} \mathrm{C}$ & 9.73 & \\
\hline
\end{tabular}

processing) for their impact on toughness of bovine $\mathrm{M}$. semitendinosus. The peak shear force of the beef expanded subsequent to cooking as the heat prompted denaturation of the myofibrillar and connective tissue proteins [123]. Peak shear force was highest for the oven-roasted beef (103 N), followed by sous vide cooking $(76 \mathrm{~N})$ and HPP-treated beef $(54 \mathrm{~N})$.
Powell et al. [96] showed that a slower cooking rate increased tenderness of dry roasted beef semitendinosus. Slower heating rate permits more opportunity for collagen solubilization, consequently contributing more to meat tenderization than in meat cooked at higher heating rates. However, sous vide cooking shear force mean values decreased at higher temperature as the temperature increased [123]. 
Liu et al. [68] reported a two-phase increase on shear force of goat meat. The first increase arises between 50 and $55{ }^{\circ} \mathrm{C}$ and the second increase between 70 and $75{ }^{\circ} \mathrm{C}$. These occurred due to the changes in sarcoplasmic protein, myofibrillar protein and collagen solubility during cooking. The first increment in shear force is expected because of the expanded strength of the perimysial connective tissue brought about by its straightening out of the crimped collagen fibres. The second increment could be created by the expanded strength of the single muscle fibres in light of the denaturation of proteins and interaction between myofibrillar and connective tissues [23]. Then again, the cooking loss expanded around 70 and $75{ }^{\circ} \mathrm{C}$ brought about higher meat toughness [23, 87].

Slower cooking methods show the higher meat tenderness. Tenderness of meat should correlate with other quality parameter like colour and cooking loss. Future research should include the energy requirement for different cooking methods for consumer's preference for meat.

\section{Effect on Meat Colour}

Meat colour is one of the critical parameter characterizing the meat quality and influencing consumer's preference. It is thought to be an indicator of meat freshness and level of meat doneness [71]. The HunterLab $L^{*}, a^{*}, b^{*}$ and the modified CIE system called CIELAB colour scales were opponent-type systems commonly used for colour measurement $[58,90]$. The parameter $a^{*}$ takes positive values for reddish colours and negative values for the greenish ones, whereas $b^{*}$ takes positive values for yellowish colours and negative values for the bluish ones. $L^{*}$ is an approximate measurement of luminosity [90]. Each colour parameter has a certain association with quality attributes, for example, the substance of fundamental compound parts in the meat, $\mathrm{pH}$ and water-holding capacity.

It is known that the myoglobin protein is the essential haeme pigment accountable for meat colour. Colour estimation in cooked meat can give reliable information about eating quality characteristics [40]. Many consumers consider the colour of cooked meat as a reliable indicator of safety and doneness. Dull-brown interiors are viewed as a sign of a well-done item, though pink appearance is identified with uncooked meats [61]. Figure 1 showed the meat colour change and crust formation during frying.

Colour opacity rises when the internal meat temperature is between 45 and $67{ }^{\circ} \mathrm{C}$ as the denaturing of the meat proteins myosin and actin, which do not add to the red colour, overrides the red colour of myoglobin [73]. Tornberg [119] reported the increase in meat colour opacity at about $35{ }^{\circ} \mathrm{C}$ due to the denaturing of myosin. At $40{ }^{\circ} \mathrm{C}$, most of the original myosin molecules have changed to

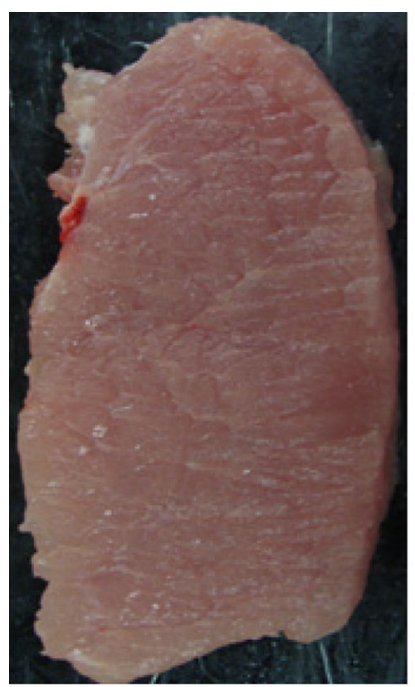

(a)

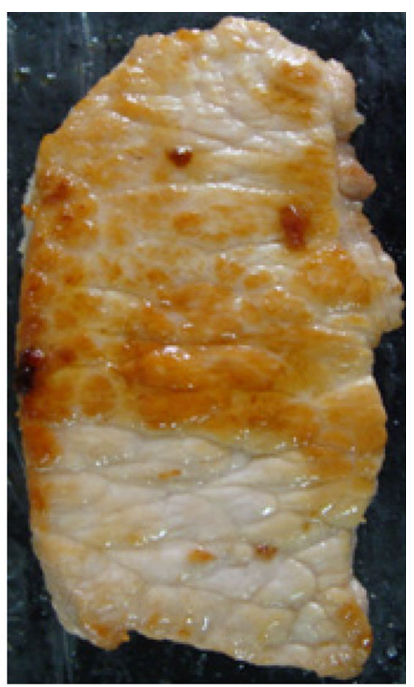

(b)
Fig. 1 Meat colour change and crust formation during frying [66]. a Raw meat, $\mathbf{b}$ colour change and crust formation

monomers with merged myosin heads. Above $50{ }^{\circ} \mathrm{C}$, myosin molecules are completely coagulated and the meat appears opaque [119]. Heated samples have more colour brightness than raw samples. In roasted samples because of dark surface, brightness was reduced but more bright colours were found inside of the samples. Generally, the samples subsequent to heating because of pigment oxidization (haeme group) become colourless [80]. Ground beef colour appearance during cooking has been affected by interconverting system of three types of myoglobin and the debasement of them through oxygenation, oxidation and reduction reactions [69].

Ohmically cooking produces more homogenous colour inside of the ground beef, while the crust layer in the surface of the ground beef could not have been achieved [14]. There was an increment in hue angle values of cooked samples contrasting with raw sample. In Sous vide cooking, the hunter laboratory parameter $a^{*}$ was strongly influenced by temperature, diminishing as the treatment temperature increased [123]. In microwave cooking, major and critical colour changes happen in short time [80].

Liu et al. [68] reported that with increasing cooking temperature, meat had a tendency to be lighter because of an expanded reflection of light, emerging from light scattering by denatured protein. The redness decreased significantly when cooking temperature increased from 50 to $80^{\circ} \mathrm{C}$ and remained at a very low value above $80^{\circ} \mathrm{C}$. As myoglobin, the most heat-stable sarcoplasmic proteins were totally denatured when meat was cooked to temperature above $80{ }^{\circ} \mathrm{C}$. Cooking temperature had influence on meat colour. It is important for consumers to select operating conditions for preferred colour meat. 


\section{Effect on Meat Shrinkage}

Shrinkage during cooking is often thought to be the poor meat quality indication by consumers. Degree of shrinkage is essential for the consumers as different thermal treatment causes undesirable changes in meat structure and increased shrinkage consider as low quality [5]. Meat shrinkage has been determined by calculating the difference between the raw and cooked areas of meat sample. The change of linear dimensions, surface and volume due to cooking have been measured. The relationship between meat water and shrinkage can be investigated and utilized as a part of meat quality examination. Recently, meat shrinkage has been measured on archiving the colour image of raw and cooked meat sample [95, 130]. However, manual shrinkage estimation is tedious and variable, as a result of its subjective nature.

According to [119], the shrinkage of meat can be summarized as: (1) the transverse shrinkage of the fibre begins at $35-40{ }^{\circ} \mathrm{C}$, it happens mainly at $40-60{ }^{\circ} \mathrm{C}$ and it broaden the gap between the fibres and their surrounding endomysium, (2) the shrinkage of the connective tissue begins at $60{ }^{\circ} \mathrm{C}$, and at $60-70{ }^{\circ} \mathrm{C}$ the connective tissue network and the muscle fibres cooperatively shrink longitudinally. The application of low temperature and long treatments could minimize the shrinkage effect during thermal processing [95]. The level of shrinkage augments with the addition in temperature and causes large water loss during cooking [119].

Meat shrinkage plays a key role in the water transport during cooking. Considerable shrinkage of meat 7-19\% on area basis [119] and 11-20.3\% on diameter basis [85] was observed. Similarly, [88] reported the diameter shrinkage varied from about $20.8 \%$ at $160{ }^{\circ} \mathrm{C}$ to about $23.5 \%$ at $200{ }^{\circ} \mathrm{C}$ for fried hamburgers with a fat content of $20 \%$.

\section{Effect on Meat Juiciness}

Meat juiciness is considered to arise out of moisture discharged by meat amid chewing, and moisture from saliva [21, 48]. Moisture loss has the influence on juiciness, which can happen by evaporation in dry heat cookery and by exudation and diffusion in moist heat cookery [46].

Cooking procedure and raw meat quality had the effect on juiciness of meat. However, to date, the only reliable and consistent measure of juiciness is accomplished using sensory methods [127]. The complexity of juiciness also causes difficulties in performing objective measurements [57].

The core temperature greatly affects juiciness of meat [1]. An increase of the centre temperature lessens the juiciness [7]. Low oven temperature will give a more juicy meat contrasted with meat cooked at a higher oven temperature with the same centre temperature [7]. In beef cooking, juiciness and cooking loss are negatively correlated, implying that a high cooking loss results in low juiciness [120]. Cooking loss has a great influence on the juiciness of meat.

\section{Heat and Mass Transfer During Meat Cooking}

Heat and mass transfer in meat products is a complex phenomenon affected by multiple physics involving energy transport, mass transport, fluid flow dynamics and mechanical deformation [16]. Differences in temperature and moisture levels between the air and the product can cause moisture evaporation from the product surface. As the product surface dries, internal moisture transport towards the product surface can occur [16]. Meat cooking environments are diverse and cooking conditions may vary over time. Hence, heat and mass transfer rates are influenced by multiple parameters including oven temperature, product load, airflow velocity, type of heating medium, and type of products (e.g. shape, dimensions, and thermal properties).

In the last two decades, computer modelling of heat transfer has gained special attention in the meat industry as it is a practical resource to estimate meat safety quantitatively. Bisceglia et al. [10] evaluated the temperature and water content dependency on cooking process time of meat samples. Finite elements software COMSOL multiphysics was used to simulate the process, and the model predicted transient temperature and moisture distributions inside the sample and transient cooking yield of meat samples during cooking was also predicted. Obuz et al. [82] developed a mathematical model to predict temperature and mass transfer of cylindrical beef roasts cooked in a forced air convection oven. The model predicted the cooking time with high accuracy.

Studies have shown that modelling of heat and mass transfer of meat products under cooking environments is a challenging task. One of the limitations of modelling cooking is that the thermal properties to great extent rely on processing and sample temperature, meat composition, component distribution and, finally, previous treatments [118]. Recently, Papasidero et al. [89] developed a computational model to correlate temperature, time and weight loss for a piece of meat cooked in oven. The model showed the good agreement with experiments.

Moisture diffusivity is an important transport parameter required for the analysis, design and optimization of all the processes that involve internal moisture movement. Moisture diffusivity $(D)$ in the meat matrix is commonly taken from reported values. Table 2 presented the published data on moisture diffusivity during meat cooking. 


\section{Thermal Diffusivity}

For heat transfer analysis, the information on thermophysical properties and that on their variations is vital [53], and to estimate cooking time, product final temperature and cooking performances [100]. Thermal diffusivity includes the effects of properties like mass density, thermal conductivity and specific heat capacity. Thermal diffusivity, which is involved in all unsteady heat conduction problems, is a property of the solid object. The physical significance of thermal diffusivity is associated with the diffusion of heat into the medium during changes of temperature with time. The higher thermal diffusivity coefficient implies the quicker penetration of the heat into the medium and the less time required to expel the heat from the solid [32]. The higher thermal diffusivity values will result in more effective heat transfer.

Thermal diffusivity depends on the thermodynamics properties of material and its internal structure. Thermal diffusivity may be affected by different mechanisms of heat and mass transfer amid cooking of meat products. Physical and chemical changes due to thermal treatment prompt changes in the material structure [72]. Table 3 presented the thermal diffusivity data during cooking.

\section{Energy Requirement for Meat Cooking}

Energy requirement for cooking can be prodigious and energy varies with different cooking methods. There are very limited studies in literature focused on the energy consumption for meat cooking. Recently, Suwannakam et al. [117] investigated the energy consumption of the combination of far-infrared and superheated steam with forced air (FIR-SS-FA) system, a combination of far-infrared and superheated steam (FIR-SS) system and a combination of force air and superheated steam (FA-SS) system for roasting skinless deboned chicken breast meat. FIR-SS-FA system showed the lowest specific energy consumption $(2.54 \mathrm{kWh} / \mathrm{kg})$, which has the shortest cooking time also. The specific energy consumption (SEC) was obtained from the input electrical energy and the quantity of meat samples used:

$\mathrm{SEC}=\frac{\text { Input electical energy }(\mathrm{kWh})}{\text { Weight of sample }(\mathrm{kg})}$

De Halleux et al. [26] used ohmic heating to cook Bolonga ham and found 211 and $252 \mathrm{~kJ} / \mathrm{kg}$ energy requirement. However, for conventional smoke cooking of Bologna ham required higher energy 1200 and $8100 \mathrm{~kJ} / \mathrm{kg}$ compared to ohmic heating [97, 98, 112].

Laycock et al. [64] used radio frequency cooking (RF) and water bath cooking for beef cooking. Radio frequency (RF) cooking is much more energy efficient than water bath cooking of beef cooking. WB cooking showed the low efficiency as it uses large amount of water to cook small amount of meat product and the large heat losses to environment.

Jouquand et al. [56] compared the microwave cooking with traditional cooking for beef burgundy cooking. Microwave cooking $(4.67 \mathrm{kWh})$ showed lower energy consumption than traditional cooking $(6.52 \mathrm{kWh})$. Cooking time has been reduced by $56 \%$ compared to traditional cooking. There are higher energy losses in traditional cooking.

Payton and Baldwin [91] compared microwave convection, forced air convention and conventional electric oven for beef steak cooking. Microwave convection oven utilizes microwaves as well as forced convection heat. Microwave convection oven required less cooking time and total cooking energy. Generally, microwaveable food is more energy efficient during cooking stages because the energy heats only the food, not the whole oven compartment. The volume of fluid or mass of food produce affected the microwave cooking energy efficiency. Compared with the conventional cooking, microwave cooking reduces the energy consumption as well as reduces the cooking time [17].

De et al. [25] developed energy-efficient cooking techniques for goat meat cooking. Pressure cooker contains the meat $(1 \mathrm{~kg})$, and water $(0.3 \mathrm{~L})$ has been kept on the stove till the time (ti) to hear the first whistle. Immediately

Table 2 Selected publications on moisture diffusivity for meat cooking

\begin{tabular}{|c|c|c|c|c|c|}
\hline Produce & Cooking method & Cooking condition & Moisture diffusivity $\left(10^{-10} \mathrm{~m}^{2} / \mathrm{s}\right)$ & Activation energy $(\mathrm{kJ} / \mathrm{mol})$ & References \\
\hline Chicken meat & Frying & $170-190{ }^{\circ} \mathrm{C} / 15 \mathrm{~min}$ & $36.50-74.20$ & 20.00 & [59] \\
\hline Chicken nuggets & Deep frying & $150-190{ }^{\circ} \mathrm{C} / 1-4 \min$ & $20.93-29.32$ & 8.04 & [79] \\
\hline Chicken nuggets & Oven baked & $200-240{ }^{\circ} \mathrm{C} / 5-25 \mathrm{~min}$ & $1.90-3.16$ & 25.70 & [79] \\
\hline Pork meat & Frying & $90-110^{\circ} \mathrm{C}$ & $15.00-302.00$ & - & [113] \\
\hline \multirow[t]{2}{*}{ Pork slice } & Superheated steam & $140{ }^{\circ} \mathrm{C} / 30 \mathrm{~min}$ & $3.31-2.47$ (seasoned pork) & 11.59 & {$[102]$} \\
\hline & & & $4.20-15.06$ (unseasoned pork) & 11.99 & \\
\hline
\end{tabular}


Table 3 Thermal diffusivity during meat cooking

\begin{tabular}{llll}
\hline Produce & Cooking method & Thermal diffusivity $\left(10^{-7} \mathrm{~m}^{2} / \mathrm{s}\right)$ & References \\
\hline Ground beef & Infrared radiation heating & $1.82-1.62$ & {$[107]$} \\
Beef meatballs & Deep-fat frying & 1.33 & {$[3]$} \\
Pork meat & Frying $\left(90,100\right.$ and $\left.110^{\circ} \mathrm{C}\right)$ & $1.12-1.83$ & {$[113]$} \\
Sausages & Frying & 3.85 & {$[33]$} \\
Mortadella bologna & Oven $\left(80,90\right.$ and $\left.100^{\circ} \mathrm{C}\right)$ & $1.38-1.45$ & {$[99]$} \\
Mortadella & Oven cooking & 2.40 & {$[15]$} \\
Lyoner type sausages & Hot water cooking & $1.35-1.52$ & {$[72]$} \\
\hline
\end{tabular}

pressure cooker is removed from the stove and kept in the closed insulated box for $30 \mathrm{~min}$ for cooking to use the stored heat in the meat. This method reported the considerable fuel energy saving and on stove time (19.25 min) compared to conventional cooking (40.51 min) applied in domestic cooking. Energy efficiency of cooking goat meat with this method is calculated to be $87 \%$ compared to $41 \%$ with conventional method of using pressure cooker. However, the authors did not conduct quality analysis for the cooked meat.

\section{Other Factor Affecting Energy Consumption}

Cooking is globally essential for food safety and decreases the energy utilization amid affecting worldwide energy demands. Residential cooking can require significant amounts of energy - approximately $7 \mathrm{MJ} / \mathrm{kg}$ food product [35]. The factors affecting the energy consumption include not only cooking process but also the production and transport efficiency of fuel sources, the appliance end use efficiency and consumer behaviour during cooking. The composition, size and shape of the cookware have the impact on energy consumption.

Energy-saving behaviours that consumers can perform during cooking includes reduced the length of the period of use, match sizes, volumes and amount of heat to the food for preparation. Selection of an appliance which consumes less energy or a non-energy-consuming device or method is also useful for energy saving [129]. Study in the UK showed that the information on energy-saving practices and supplying real-time energy consumption meter display could reduce the cooking energy usage up to $20 \%$ [128].

Cooking is a universal and indispensable process for meat and other fresh product consumption as well as food safety. Thus, implementing policies/practices that lessen energy utilization amid cooking will significantly affect worldwide energy demands. Most of the GHG discharges are identified with home processing, especially to energy use for cooking, which represented between 50 and $70 \%$ of overall GHG emissions [36]. Therefore, more efficient meat cooking methods would achieve reductions in energy use and reduce the carbon footprints of food production.
Alternative sources such as biomass and solar energy may reduce energy uses for meat cooking. The use of wood as cooking fuel (fuel wood) in order to meet the cooking energy requirement, due to high cost of alternative energy source, results in deforestation and adverse environmental effects. Hence, there is the need for more research to develop low-cost and environmentally friendly alternatives such biogas cooker and solar cookers and utilize renewable energy sources that would diminish the dependence on traditional fuels. It could help in conservation of conventional fuels in developing countries and electricity/gas in the developed areas.

In meat cooking, it is important to increase the use of energy from renewable sources, together with energy efficient cooking methods to reduce GHG emissions. Future research should focus on redesigning and improving meat cooking processes. Cooking energy demand should be optimized by improving real-time cooking data, and benchmarking can identify the opportunities to reduce demand.

\section{Conclusions}

Comprehensive review of literature showed that cooking methods play a major role in eating quality attributes. Selection of operating conditions not only affected the meat quality but also the efficiency of the applied cooking process. Improvement of the current cooking practices or investigating new cooking strategies is essential for the meat processing industry. Therefore, research should focus more on evaluating the optimum cooking process for highquality and energy-efficient meat cooking. This will enable the consumer's to make proper selection cooking methods and processing parameter of meat cooking. Furthermore, research on cooking technology applicable in reducing energy requirement for cooking for commercial and domestic purposes should be emphasized.

Energy efficiency or energy required for cooking is very important area to emphasis as limited studied focused on energy consumption. It is important to focus the study, which correlate the meat quality and consumers preference 
related to meat cooking. This includes the energy for different cooking processes. There are many studies on meat quality; however, energy consumption is also main requirement. Innovative methods like microwave cooking reduce the energy requirement compared to traditional cooking that causes higher cooking losses. It is important that these parameters should be optimized for energy-efficient quality meat cooking process.

Renewable energy can be used for meat cooking. As energy-efficient cooking is not always the consumer's eating preference. It is important to investigate energy-efficient cooking technique to conserve most extreme energy amid cooking and to secure meat quality parameter. In addition dialogue and education to consumers are needed to reduce energy consumption without compromising the quality meat products.

Acknowledgments The authors gratefully acknowledge the financial support from European Commission's Intelligent Energy Europe (IEE) scheme (European Commission grant agreement: IEE/12/723/ S.12.645697- GREENFOODS) and Engineering and Physical Science Research Council, UK (RE4Food project -EP/L002531/1).

Open Access This article is distributed under the terms of the Creative Commons Attribution 4.0 International License (http://crea tivecommons.org/licenses/by/4.0/), which permits unrestricted use, distribution, and reproduction in any medium, provided you give appropriate credit to the original author(s) and the source, provide a link to the Creative Commons license, and indicate if changes were made.

\section{References}

1. Aaslyng MD, Bejerholm C, Ertbjerg P, Bertram HC, Andersen $\mathrm{HJ}$ (2003) Cooking loss and juiciness of pork in relation to raw meat quality and cooking procedure. Food Qual Prefer 14(4):277-288

2. Alvis A, Vélez C, Rada-Mendoza M, Villamiel M, Villada HS (2009) Heat transfer coefficient during deep-fat frying. Food Control 20(4):321-325

3. Ateba P, Mittal GS (1994) Modelling the deep-fat frying of beef meatballs. Int J Food Sci Technol 29(4):429-440

4. Bailey AJ, Light ND (1989) Connective tissue in meat and meat Products. Elsevier Science Publishers Ltd, London

5. Barbera S, Tassone S (2006) Meat cooking shrinkage: measurement of a new meat quality parameter. Meat Sci 73(3): 467-474

6. Bejerholm C, Aaslyng MD (2004) Cooking of meat. Encyclopedia of meat sciences. Elsevier Science and Technology, Philadelphia, pp 343-349

7. Bejerholm C, Aaslyng MD (2004) The influence of cooking technique and core temperature on results of a sensory analysis of pork-depending on the raw meat quality. Food Qual Prefer 15(1):19-30

8. Białobrzewski I, Danowska-Oziewicz M, Karpińska-Tymoszczyk M, Nalepa B, Markowski M, Myhan R (2010) Turkey breast roasting - process optimization. J Food Eng 96(3):394-400

9. Biesalski HK (2005) Meat as a component of a healthy diet-are there any risks or benefits if meat is avoided in the diet? Meat Sci 70(3):509-524
10. Bisceglia B, Brasiello A, Pappacena R, Vietri R (2013) Food cooking process. Numerical simulation of the transport phenomena. In: Department of industrial engineering, University of Salerno, Via Giovanni Paolo II, COMSOL Conference in Rotterdam, Italy

11. Bognar A (1998) Comparative study of frying to other cooking techniques influence on the nutritive value. Grasas Aceites 49(3-4):250-260

12. Boleman SJ, Boleman SL, Miller RK, Taylor JF, Cross HR, Wheeler TL, Koohmaraie M, Shackelford SD, Miller MF, West RL (1997) Consumer evaluation of beef of known categories of tenderness. J Anim Sci 75(6):1521-1524

13. Bozkurt H, Icier F (2010) Electrical conductivity changes of minced beef-fat blends during ohmic cooking. J Food Eng 96(1):86-92

14. Bozkurt H, Icier F (2010) Ohmic cooking of ground beef: effects on quality. J Food Eng 96(4):481-490

15. Carciofi BAM, Faistel J, Aragão GMF, Laurindo JB (2002) Determination of thermal diffusivity of mortadella using actual cooking process data. J Food Eng 55(1):89-94

16. Cepeda JF, Weller CL, Negahban M, Subbiah J, Thippareddi H (2013) Heat and mass transfer modeling for microbial food safety applications in the meat industry: a review. Food Eng Rev 5(2):57-76

17. Chang HJ, Xu XL, Li CB, Huang M, Liu DY, Zhou GH (2011) A comparison of heat-induced changes of intramuscular connective tissue and collagen of beef semitendinosus muscle during water bath and microwave heating. J Food Process Eng 34(6):2233-2250

18. Cheftel JC, Culioli J (1997) Effects of high pressure on meat: a review. Meat Sci 46(3):211-236

19. Cheng Q, Sun D-W, Scannell AGM (2005) Feasibility of water cooking for pork ham processing as compared with traditional dry and wet air cooking methods. J Food Eng 67(4):427-433

20. Chiavaro E, Rinaldi M, Vittadini E, Barbanti D (2009) Cooking of pork Longissimus dorsi at different temperature and relative humidity values: effects on selected physico-chemical properties. J Food Eng 93(2):158-165

21. Christensen CM (1984) Food texture perception. Adv Food Res 29:159-199

22. Christensen L, Ertbjerg P, Aaslyng MD, Christensen M (2011) Effect of prolonged heat treatment from 48 to $63{ }^{\circ} \mathrm{C}$ on toughness, cooking loss and color of pork. Meat Sci 88(2):280-285

23. Combes S, Lepetit J, Darche B, Lebas F (2004) Effect of cooking temperature and cooking time on Warner-Bratzler tenderness measurement and collagen content in rabbit meat. Meat Sci 66(1):91-96

24. Dai Y, Q-n Zhang, Wang L, Liu Y, X-m Li, R-t Dai (2014) Changes in shear parameters, protein degradation and ultrastructure of pork following water bath and ohmic cooking. Food Bioprocess Technol 7(5):1393-1403

25. De DK, Nathaniel M, Olawole O (2014) Cooking with minimum energy and protection of environments and health. IERI Proc 9:148-155

26. De Halleux D, Piette G, Buteau ML, Dostie M (2005) Ohmic cooking of processed meats: energy evaluation and food safety considerations. Can Biosyst Eng 47(3):341-347

27. de Lamballerie-Anton M, Taylor RG, Culioli J (2002) High pressure processing of meat. In: Kerry JS, Kerry JH, Ledward D (eds) Meat processing: improving quality. CRC Press, New York, pp 313-331

28. Delgado EJ, Rubio MS, Iturbe FA, Méndez RD, Cassís L, Rosiles R (2005) Composition and quality of Mexican and imported retail beef in Mexico. Meat Sci 69(3):465-471

29. DeMan JM (1976) Rheology and texture in food quality. Avi Publishing Company, Westport, Connecticut 
30. Destefanis G, Brugiapaglia A, Barge MT, Dal Molin E (2008) Relationship between beef consumer tenderness perception and Warner-Bratzler shear force. Meat Sci 78(3):153-156

31. Díaz P, Nieto G, Garrido MD, Bañón S (2008) Microbial, physical-chemical and sensory spoilage during the refrigerated storage of cooked pork loin processed by the sous vide method. Meat Sci 80(2):287-292

32. Dincer I, Dost S (1995) Thermal diffusivities of geometrical objects subjected to cooling. Appl Energy 51(2):111-118

33. Dincer I, Yildiz M (1996) Modelling of thermal and moisture diffusions in cylindrically shaped sausages during frying. J Food Eng 28(1):35-44

34. Domínguez R, Gómez M, Fonseca S, Lorenzo JM (2014) Effect of different cooking methods on lipid oxidation and formation of volatile compounds in foal meat. Meat Sci 97(2):223-230

35. Dutilh CE, Kramer KJ (2000) Energy consumption in the food chain: comparing alternative options in food production and consumption. Ambio A J Hum Environ 29(2):98-101

36. Edwards-Jones G, Plassmann K, York EH, Hounsome B, Jones DL, Milà i Canals L (2009) Vulnerability of exporting nations to the development of a carbon label in the United Kingdom. Environ Sci Policy 12(4):479-490

37. El-Shimi NM (1992) Influence of microwave and conventional cooking and reheating on sensory and chemical characteristics of roast beef. Food Chem 45(1):11-14

38. Farkas BE, Singh RP, Rumsey TR (1996) Modeling heat and mass transfer in immersion frying. I, model development. J Food Eng 29(2):211-226

39. Garcia-Arias MT, Pontes EÁ, Garcia-Linares MC, Garcia-Fernandez MC, Sanchez-Muniz FJ (2003) Cooking-freezing-reheating (CFR) of sardine (Sardina pilchardus) fillets. Effect of different cooking and reheating procedures on the proximate and fatty acid compositions. Food Chem 83(3):349-356

40. García-Segovia P, Andrés-Bello A, Martínez-Monzó J (2007) Effect of cooking method on mechanical properties, color and structure of beef muscle (M. pectoralis). J Food Eng 80(3):813-821

41. Girard I, Bruce HL, Basarab JA, Larsen IL, Aalhus JL (2012) Contribution of myofibrillar and connective tissue components to the Warner-Bratzler shear force of cooked beef. Meat Sci 92(4):775-782

42. Goñi SM, Salvadori VO (2010) Prediction of cooking times and weight losses during meat roasting. J Food Eng 100(1):1-11

43. Hager TJ, Morawicki R (2013) Energy consumption during cooking in the residential sector of developed nations: a review. Food Policy 40:54-63

44. Harris PV (1976) Structural and other aspects of meat tenderness. J Texture Stud 7:49-63

45. Hearne LE, Penfield MP, Goertz GE (1978) Heating effects on bovine semitendinosus: shear, muscle fiber measurements, and cooking losses. J Food Sci 43(1):10-12

46. Hernández P, Navarro JL, Toldrá F (1999) Lipids of pork meat as affected by various cooking techniques/Modificaciones de los lípidos de carne de cerdo en función de su guiso. Food Sci Technol Int 5(6):501-508

47. Holcomb DN, Kalab M (1981) Studies of food microstructure. Scanning Electron Microscopy Inc, New York

48. Howard A (1976) Psychometric scaling of sensory texture attributes of meat. J Texture Stud 7(1):95-107

49. Huffman KL, Miller MF, Hoover LC, Wu CK, Brittin HC, Ramsey CB (1996) Effect of beef tenderness on consumer satisfaction with steaks consumed in the home and restaurant. J Anim Sci 74(1):91-97

50. Hugas M, Garriga M, Monfort JM (2002) New mild technologies in meat processing: high pressure as a model technology. Meat Sci 62(3):359-371
51. Icier F, Ilicali C (2005) The use of tylose as a food analog in ohmic heating studies. J Food Eng 69(1):67-77

52. Icier F, Sengun IY, Yildiz Turp G, Arserim EH (2014) Effects of process variables on some quality properties of meatballs semicooked in a continuous type ohmic cooking system. Meat Sci 96(3):1345-1354

53. Jain D, Pathare PB (2007) Determination of thermal diffusivity of freshwater fish during ice storage by using a one-dimensional Fourier cylindrical equation. Biosyst Eng 96(3):407-412

54. James BJ, Yang SW (2012) Effect of cooking method on the toughness of bovine m. semitendinosus. Int J Food Eng 8(2). doi:10.1515/1556-3758.2762

55. Janicki LJ, Appledorf H (1974) Effect of broiling, grill frying and microwave cooking on moisture, some lipid components and total fatty acids of ground beef. J Food Sci 39(4):715-717

56. Jouquand C, Tessier FJ, Bernard J, Marier D, Woodward K, Jacolot P, Gadonna-Widehem P, Laguerre J-C (2015) Optimization of microwave cooking of beef burgundy in terms of nutritional and organoleptic properties. LWT Food Sci Technol 60(1):271-276

57. Juárez M, Aldai N, López-Campos Ó, Dugan MER, Uttaro B, Aalhus JL (2012) Beef texture and juiciness. In: Hui YH (ed) Handbook of meat and meat processing, 2nd edn. CRC Press, Boca Raton, pp 177-206

58. Karamucki T, Gardzielewska J, Rybarczyk A, Jakubowska M, Natalczyk-Szymkowska W (2011) Usefulness of selected methods of colour change measurement for pork quality assessment. Czech J Food Sci 29(3):212-218

59. Kassama LS, Ngadi MO (2005) Pore development and moisture transfer in chicken meat during deep-fat frying. Dry Technol 23(4):907-923

60. Ken K, Atsushi S, Tadayuki N, Yoshihide I, Hiroyuki T (2006) Application of high hydrostatic pressure to meat and meat processing. In: Nollet LML, Toldra F (eds) Advanced technologies for meat processing. Food science and technology. CRC Press, Boca Raton, pp 193-217

61. King NJ, Whyte R (2006) Does it look cooked? a review of factors that influence cooked meat color. J Food Sci 71(4):R31R40

62. Kondjoyan A, Kohler A, Realini CE, Portanguen S, Kowalski R, Clerjon S, Gatellier P, Chevolleau S, Bonny J-M, Debrauwer L (2014) Towards models for the prediction of beef meat quality during cooking. Meat Sci 97(3):323-331

63. Kondjoyan A, Oillic S, Portanguen S, Gros J-B (2013) Combined heat transfer and kinetic models to predict cooking loss during heat treatment of beef meat. Meat Sci 95(2):336-344

64. Laycock L, Piyasena P, Mittal GS (2003) Radio frequency cooking of ground, comminuted and muscle meat products. Meat Sci 65(3):959-965

65. Lepetit J (2007) A theoretical approach of the relationships between collagen content, collagen cross-links and meat tenderness. Meat Sci 76(1):147-159

66. Li C, Hu Y, Tang L, Dong Y, Teng A, Xu X, Xu B, Zhou G (2012) Changes in temperature profile, texture and color of pork loin chop during pan-frying. J Food Res 1(3):p184

67. Li C, Wang D, Dong H, Xu W, Gao F, Zhou G, Zhang M (2013) Effects of different cooking regimes on the microstructure and tenderness of duck breast muscle. J Sci Food Agric 93(8): 1979-1985

68. Liu F, Meng L, Gao X, Li X, Luo H, Dai R (2013) Effect of end point temperature on cooking losses, shear force, color, protein solubility and microstructure of goat meat. J Food Process Preserv 37(3):275-283

69. Liu Y, Chen Y-R (2001) Analysis of visible reflectance spectra of stored, cooked and diseased chicken meats. Meat Sci 58(4):395-401 
70. Lorenzen CL, Calkins CR, Green MD, Miller RK, Morgan JB, Wasser BE (2010) Efficacy of performing Warner-Bratzler and slice shear force on the same beef steak following rapid cooking. Meat Sci 85(4):792-794

71. Mancini RA, Hunt M (2005) Current research in meat color. Meat Sci 71(1):100-121

72. Markowski M, Bialobrzewski I, Cierach M, Paulo A (2004) Determination of thermal diffusivity of Lyoner type sausages during water bath cooking and cooling. J Food Eng 65(4):591-598

73. Martens H, Stabursvik E, Martens M (1982) Texture and colour changes in meat during cooking related to thermal denaturation of muscle proteins1. J Texture Stud 13(3):291-309

74. Mir-Bel J, Oria R, Salvador ML (2012) Influence of temperature on heat transfer coefficient during moderate vacuum deep-fat frying. J Food Eng 113(2):167-176

75. Mor-Mur M, Yuste J (2003) High pressure processing applied to cooked sausage manufacture: physical properties and sensory analysis. Meat Sci 65(3):1187-1191

76. Mora B, Curti E, Vittadini E, Barbanti D (2011) Effect of different air/steam convection cooking methods on turkey breast meat: physical characterization, water status and sensory properties. Meat Sci 88(3):489-497

77. Mortensen LM, Frøst MB, Skibsted LH, Risbo J (2012) Effect of time and temperature on sensory properties in low-temperature long-time sous-vide cooking of beef. J Culin Sci Technol 10(1):75-90

78. Murphy RY, Johnson ER, Duncan LK, Clausen EC, Davis MD, March JA (2001) Heat transfer properties, moisture loss, product yield, and soluble proteins in chicken breast patties during air convection cooking. Poult Sci 80(4):508-514

79. Ngadi M, Dirani K, Oluka S (2006) Mass transfer characteristics of chicken nuggets. Int J Food Eng 2(3). doi:10.2202/15563758.1071

80. Nikmaram P, Yarmand MS, Emamjomeh Z, Darehabi HK (2011) The effect of cooking methods on textural and microstructure properties of veal muscle (Longissimus dorsi). Global Vet 6(2):201-207

81. Obuz E, Dikeman ME, Loughin TM (2003) Effects of cooking method, reheating, holding time, and holding temperature on beef longissimus lumborum and biceps femoris tenderness. Meat Sci 65(2):841-851

82. Obuz E, Powell TH, Dikeman ME (2002) Simulation of cooking cylindrical beef roasts. LWT Food Sci Technol 35(8):637-644

83. Omojola AB, Hammed S, Attoh-Kotoku V, Wogar GSI, Iyanda OD, Aremo JO (2014) Physico chemical and organoleptic characteristics of Muscovy drake meat as influenced by cooking methods. Afr J Food Sci 8(4):184-189

84. Oroszvári BK, Bayod E, Sjöholm I, Tornberg E (2006) The mechanisms controlling heat and mass transfer on frying of beefburgers. III. Mass transfer evolution during frying. J Food Eng 76(2):169-178

85. Oroszvári BK, Sjöholm I, Tornberg E (2005) The mechanisms controlling heat and mass transfer on frying of beefburgers. I. The influence of the composition and comminution of meat raw material. J Food Eng 67(4):499-506

86. Özkan N, Ho I, Farid M (2004) Combined ohmic and plate heating of hamburger patties: quality of cooked patties. J Food Eng 63(2):141-145

87. Palka K, Daun H (1999) Changes in texture, cooking losses, and myofibrillar structure of bovine M. semitendinosus during heating. Meat Sci 51(3):237-243

88. Pan Z, Singh RP (2001) Physical and thermal properties of ground beef during cooking. LWT Food Sci Technol 34(7):437-444
89. Papasidero D, Pierucci S, Manenti F, Piazza L (2015) Heat and mass transfer in roast beef cooking. Temperature and weight loss prediction. Chem Eng Trans 43:151-156

90. Pathare PB, Opara UL, Al-Said FA-J (2013) Colour measurement and analysis in fresh and processed foods: a review. Food Bioprocess Technol 6(1):36-60

91. Payton J, Baldwin RE (1985) Comparison of top round steaks cooked by microwaveconvection, forced-air convection and conventional ovens. J Microw Power 4:255-259

92. Pereira PMDCC, Vicente AFDRB (2013) Meat nutritional composition and nutritive role in the human diet. Meat Sci 93(3):586-592

93. Pietrasik Z, Dhanda JS, Pegg RB, Shand PJ (2005) The effects of marination and cooking regimes on the waterbinding properties and tenderness of beef and bison top round roasts. J Food Sci 70(2):S102-S106

94. Pokorny J (1999) Changes of nutrients at frying temperatures. In: Boskou D, Edmalfa I (eds) Frying of food Oxidation, nutrient and non-nutrient antioxidants, biologically active compounds and high temperatures. Technomic, Lancaster, PA, pp 69-103

95. Półtorak A, Wyrwisz J, Moczkowska M, Marcinkowska-Lesiak M, Stelmasiak A, Rafalska U, Wierzbicka A, Sun D-W (2015) Microwave vs. convection heating of bovine Gluteus Medius muscle: impact on selected physical properties of final product and cooking yield. Int J Food Sci Technol 50(4):958-965

96. Powell TH, Dikeman ME, Hunt MC (2000) Tenderness and collagen composition of beef semitendinosus roasts cooked by conventional convective cooking and modeled, multi-stage, convective cooking. Meat Sci 55(4):421-425

97. Reichert JE (1991) Die optimierung von wãrmebehandlungsbedingungen. Die Fleischerei 42(10):786-790

98. Reichert JE, Thumel H (1986) Zur Ermittlung des Erhitzungseffektes von Frischware (F-Wert). Die Fleischerei 37(4):352-354

99. Rinaldi M, Chiavaro E, Gozzi E, Massini R (2011) Simulation and experimental validation of simultaneous heat and mass transfer for cooking process of Mortadella Bologna PGI. Int J Food Sci Technol 46(3):586-593

100. Rinaldi M, Chiavaro E, Massini R (2010) Apparent thermal diffusivity estimation for the heat transfer modelling of pork loin under air/steam cooking treatments. Int J Food Sci Technol 45(9):1909-1917

101. Rodriguez-Estrada MT, Penazzi G, Caboni MF, Bertacco G, Lercker G (1997) Effect of different cooking methods on some lipid and protein components of hamburgers. Meat Sci 45(3):365-375

102. Sa-adchom P, Swasdisevi T, Nathakaranakule A, Soponronnarit S (2011) Mathematical model of pork slice drying using superheated steam. J Food Eng 104(4):499-507

103. Sastry SK, Li Q (1996) Modeling the ohmic heating of foods. Food Technol 50(5):246-248

104. Seideman SC, Durland PR (1984) The effect of cookery on muscle proteins and meat palatability: a review. J Food Qual 6(4):291-314

105. Sen AR, Naveena BM, Muthukumar M, Vaithiyanathan S (2014) Colour, myoglobin denaturation and storage stability of raw and cooked mutton chops at different end point cooking temperature. J Food Sci Technol 51(5):970-975

106. Sengun IY, Yildiz Turp G, Icier F, Kendirci P, Kor G (2014) Effects of ohmic heating for pre-cooking of meatballs on some quality and safety attributes. LWT Food Sci Technol 55(1):232-239

107. Sheridan PS, Shilton NC (2002) Determination of the thermal diffusivity of ground beef patties under infrared radiation ovenshelf cooking. J Food Eng 52(1):39-45 
108. Shirsat N, Brunton NP, Lyng JG, McKenna B, Scannell A (2004) Texture, colour and sensory evaluation of a conventionally and ohmically cooked meat emulsion batter. J Sci Food Agric 84(14):1861-1870

109. Shirsat N, Lyng JG, Brunton NP, McKenna B (2004) Ohmic processing: electrical conductivities of pork cuts. Meat Sci 67(3):507-514

110. Silva DRG, Torres Filho RA, Cazedey HP, Fontes PR, Ramos ALS, Ramos EM (2015) Comparison of Warner-Bratzler shear force values between round and square cross-section cores from cooked beef and pork Longissimus muscle. Meat Sci 103:1-6

111. Simonin H, Duranton F, de Lamballerie M (2012) New insights into the high-pressure processing of meat and meat products. Compr Rev Food Sci Food Saf 11(3):285-306

112. Singh RP (1986) Energy in food processing. Elsevier, New York

113. Sosa-Morales ME, Orzuna-Espíritu R, Vélez-Ruiz JF (2006) Mass, thermal and quality aspects of deep-fat frying of pork meat. J Food Eng 77(3):731-738

114. Soyer A, Ertaş AH, Üzümcüoğlu Ü (2005) Effect of processing conditions on the quality of naturally fermented Turkish sausages (sucuks). Meat Sci 69(1):135-141

115. Stirling R (1987) Ohmic heating - a new process for the food industry. Power Eng J 1(6):365-371

116. Sun XD, Holley RA (2010) High hydrostatic pressure effects on the texture of meat and meat products. J Food Sci 75(1):R17R23

117. Suwannakam M, Noomhorm A, Anal AK (2014) Influence of combined far-infrared and superheated steam for cooking chicken meat patties. J Food Process Eng 37(5):515-523

118. Tocci AM, Mascheroni RH (1995) Heat and mass transfer coefficients during the refrigeration, freezing and storage of meats, meat products and analogues. J Food Eng 26(2):147-160

119. Tornberg E (2005) Effects of heat on meat proteins-implications on structure and quality of meat products. Meat Sci 70(3):493-508

120. Toscas PJ, Shaw FD, Beilken SL (1999) Partial least squares (PLS) regression for the analysis of instrument measurements and sensory meat quality data. Meat Sci 52(2):173-178

121. Vardag T, Körner P (1995) High pressure: a real alternative in food processing. Food Mark Technol 9(1):42

122. Varela G (1988) Current facts about the frying of food. In: Varela G, Bender AE, Morton ID (eds) Frying of food. Principles, changes, new approaches. Ellis Horwood Ltd., Chichester, pp 9-25

123. Vaudagna SR, Sánchez G, Neira MS, Insani EM, Picallo AB, Gallinger MM, Lasta JA (2002) Sous vide cooked beef muscles: effects of low temperature-long time (LT-LT) treatments on their quality characteristics and storage stability. Int J Food Sci Technol 37(4):425-441

124. Vittadini E, Rinaldi M, Chiavaro E, Barbanti D, Massini R (2005) The effect of different convection cooking methods on the instrumental quality and yield of pork Longissimus dorsi. Meat Sci 69(4):749-756

125. Wang R, Farid MM (2015) Corrosion and health aspects in ohmic cooking of beef meat patties. J Food Eng 146:17-22

126. Willems MET, Purslow PP (1997) Mechanical and structural characteristics of single muscle fibres and fibre groups from raw and cooked pork longissimus muscle. Meat Sci 46(3):285-301

127. Winger RJ, Hagyard CJ (1994) Juiciness-its importance and some contributing factors. In: Pearson AM, Dutson TR (eds) Quality attributes and their measurement in meat, poultry and fish products. Blackie Academic and Professional, London, pp 94-124

128. Wood G, Newborough M (2003) Dynamic energy-consumption indicators for domestic appliances: environment, behaviour and design. Energy Build 35(8):821-841

129. Wood G, Newborough M (2007) Influencing user behaviour with energy information display systems for intelligent homes. Int J Energy Res 31(1):56-78

130. Wyrwisz J, Półtorak A, Poławska E, Pierzchała M, JÓŹWik A, Zalewska M, Zaremba R, Wierzbicka A (2012) The impact of heat treatment methods on the physical properties and cooking yield of selected muscles from Limousine breed cattle. Anim Sci Papers Rep 30(4):339-351

131. Xu Z, Sun D-W, Zhang Z, Zhu Z (2015) Research developments in methods to reduce carbon footprint of cooking operations: a review. Trends Food Sci Technol 44(1):49-57

132. Yarmand MS, Homayouni A (2009) Effect of microwave cooking on the microstructure and quality of meat in goat and lamb. Food Chem 112(4):782-785

133. Yarmand MS, Nikmaram P, Emam Djomeh Z, Homayouni A (2013) Microstructural and mechanical properties of camel longissimus dorsi muscle during roasting, braising and microwave heating. Meat Sci 95(2):419-424

134. Yildiz-Turp G, Sengun IY, Kendirci P, Icier F (2013) Effect of ohmic treatment on quality characteristic of meat: a review. Meat Sci 93(3):441-448

135. Zell M, Lyng JG, Cronin DA, Morgan DJ (2009) Ohmic cooking of whole beef muscle-optimisation of meat preparation. Meat Sci 81(4):693-698

136. Zell M, Lyng JG, Cronin DA, Morgan DJ (2010) Ohmic cooking of whole turkey meat-effect of rapid ohmic heating on selected product parameters. Food Chem 120(3):724-729 